\title{
Center for Sorghum Entrepreneurship (CSE) Supports the Diversification and Food Security Program
}

\author{
E Noerhartati ${ }^{1}, \mathrm{~T}$ Widiartin ${ }^{2}$, Maslihah $^{2}$, NW Karyanto ${ }^{2}$, S Azizah $^{3}$, LT Muharlisiani $^{3}$, \\ Soepriyono ${ }^{4}$, PD Karyati ${ }^{5}$, B Yunarko ${ }^{6}$ \\ \{endang_noer@uwks.ac.id, widiartin@gmail.com, lika.btr@gmail.com, nonotwik@gmail.com, \\ sitiazizah_fbs@uwks.ac.id, lusytm_fbs@uwks.ac.id, priyonohs@yahoo.co.id, \\ pratiwidwikarjati@uwks.ac.id, bambang_yunarko@uwks.ac.id\}
}

\begin{abstract}
Department of Agroindustrial Technology, Universitas Wijaya Kusuma Surabaya, Indonesia ${ }^{1}$, Department of Informatic Engineering, Universitas Wijaya Kusuma Surabaya, Indonesia ${ }^{2}$, Department of English Education, Universitas Wijaya Kusuma Surabaya ${ }^{3}$, Department of Civil Engineering, Universitas

Wijaya Kusuma Surabaya, Indonesia ${ }^{4}$, Department of Economic Development, Universitas Wijaya

Kusuma Surabaya, Indonesia ${ }^{5}$, Department of Law, Universitas Wijaya Kusuma Surabaya, Indonesia ${ }^{6}$
\end{abstract}

\begin{abstract}
Sorghum is food source has been developed in Universitas Wijaya Kusuma Surabaya (UWKS) since 2009 up to now by doing Tri Dharma Perguruan Tinggi. Sorghum plant can be utilized especially to support diversification program and food sustainability: rice, flour and soft bran, and liquid stem sugar sorghum. IbIKK program is Science and Technology for Innovation and Creativity of Campus, since 2016 it has been done the development of entrepreneurship as Center for Sorghum Entrepreneurship and developed Sorghum Entrepreneurship Unit (SEU) has 26 units: students, lecturers, and employees of UWKS as well as community. The gradual development of SEU includes training and assistance in the manufacture of various sorghum products, supporting equipment, and sorghum product competition made from rice and flour of sorghum. It's achievement is UWKS able to contribute and provide solution to the nation of Indonesia through the diversification of sorghum food, raising the potential of sorghum as alternative food, opening opportunities sorghum industry, created new entrepreneurs in the field of sorghum. by becoming CSE, UWKS can support the program of can support the Indonesian Food Diversification and Food Security Program, also support the stabilization of production of natural sweeteners.
\end{abstract}

Keywords: Sorghum, rice and flour, natural sweeteners, security

\section{Introduction}

Since 2009, UWKS has begun researches on "Development of Sorghum as an Alternative Food", where the results of research show that sorghum can be used as a substitute for various flour: flour, sticky rice flour, rice flour, and others. Starting from grains which can be processed into rice, flour, rice bran, various flour processed products into various wet cakes: nagasari, lapis, solo sausages, dumplings, etc. [1], as well as various pastries: sticks [2], pies, and various cookies [3] , and there are still results of research from sorghum stems that can be processed into sorghum stem syrup[4]. At the same time UWKS collaborated and formed a network of sorghum producers in several areas on Java. In this connection, the UWKS has established a target area and selected several sorghum farmer groups in East Java as 
development partners for sorghum processed products, namely Lamongan, Bangkalan, Sampang, Probolinggo, Pasuruan, Bojonegoro and Pacitan [5].

Sorghum also has other advantages in terms of health, namely "gluten free", more fiber, and contains antioxidants. contains tannin, and antioxidants. The benefits of sorghum for health are: as nutritious food, containing high fiber so that it is good for digestion, can be used as diabetes control, gluten free which can prevent celiac disease, contains calcium good for bone health, can increase circulation and red blood cell production, increase energy, and cancer prevention [6-9]

Table 1. The Nutrient Content of Sorghum Compared with Other Food Resource

\begin{tabular}{lcccccc}
\hline \hline \multirow{2}{*}{ Nutrient Uptake } & \multicolumn{7}{c}{ Content /100 g } \\
\cline { 2 - 7 } & Wheat & Rice & Sorghum & Cassava & Corn & Soybean \\
\hline \hline Cal (cal) & 365 & 360 & 332 & 146 & 361 & 286 \\
Protein (g) & 8.9 & 6.8 & 11.0 & 1.2 & 8.7 & 30.2 \\
Fat (g) & 1.3 & 0.7 & 3.3 & 0.3 & 4.5 & 15.6 \\
Carbohydrate (g) & 77 & 78.9 & 73.0 & 34.7 & 72.4 & 30.1 \\
Ca (mg) & 16 & 6.0 & 28.0 & 33.0 & 9.0 & 196.0 \\
Fe (mg) & 1.2 & 0.8 & 4.4 & 0.7 & 4.6 & 6.9 \\
P (mg) & 106 & 140 & 287 & 40 & 380 & 506 \\
Vit. B1 (mg) & 0 & 0.12 & 0.38 & 0.06 & 0.27 & 0.93 \\
\hline
\end{tabular}

Source: [10]

Research and community service activities related to various sorghum processed products from 2009 until now: processing rice and sorghum flour[11], sorghum cookies [12], stem syrup sorghum [13][14], sorghum pie [15], various sorghum wet cakes [16], sorghum wet noodles [17], sorghum flakes [18], sorghum soft bran [19], IbIKK sentra processed production of sorghum products in UWKS [20], increased capability of sorghum products as alternative food stuffs, Sorghum functional drinks [21][22], and building network of entrepreneurship [23]. Based on the results of research and community service by IbIKK program is Science and Technology for Innovation and Creativity of Campus, it will be more optimizing than the potential of sorghum plants, which in the end the product will be a product of innovation and development of science and technology and culture (applied research) that can be utilized by society or industry.

\section{Methods}

Research following the CSE supporting is conducted by three steps methodology as described below:

a. The need assessment survey was conducted to cover the need for supporting programs to promote sorghum commodities to become alternative food for residents of urban communities. This was done through a series of reviews on the activities of the UWKS team so far in sorghum production centers and market acceptance of processed products in urban areas. Besides that, a survey was also conducted through in-depth interviews with stakeholders in developing sorghum commodities in East Java.

b. The second step is development programs named as IbIKK program, as a formulation of program action results from the need assessment survey. The most important 
formula of this program is the establishment of CSE as a forum for developing sorghum processing entrepreneurs.

c. The next stage is Project Benefit, Monitoring and Evaluation (PBME) as an effort to measure benefits, and steps to monitor and evaluate CSE so that it can grow and be sustainable. Data analysis: actualization of UWKS as CSE and SEU [24][25].

\section{Results and Discussion}

Program development named as IbIKK is presented in Figure 1 as follows:

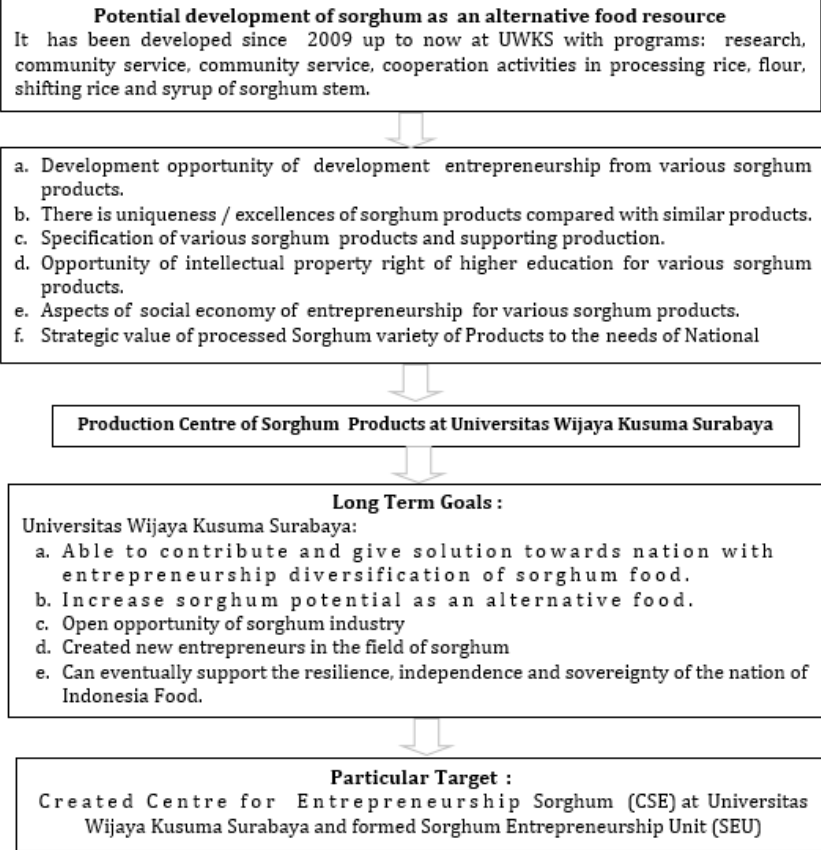

Fig, 1. Program Development of IbIKK

The IbIKK program includes: 1) realizing the CSE at UWKS; 2) development of entrepreneurship networks by SEU; SEU consists of students, lecturers, and employees from UWKS, as well as the community; 4) the development of SEU in stages includes training and assistance in the manufacture of various sorghum products, assistance with supporting equipment, information dissemination and marketing [26][27]. Sorghum-based food products are currently not available on the market, which are only available in various places for exhibition activities, so that competitors of sorghum products can be concluded that they do not yet exist . Consumer predictions of various sorghum-based processed products are from all groups and all ages, this is due to the variety of sorghum processed products. As an example of various wet cakes (nagasari, lumpur, onde-onde), consumers from all walks of life are interested, if donuts are in demand by children, pastries (sticks, pies, and various cookies) are also in demand by consumers from the community. While sorghum stem syrup products are packaged in tightly sealed bottle packs and can be consumed by all ages. Consumers must be 
given many food alternatives, one of which is sorghum-based which has many advantages and can be compared with other food products, namely, rice, corn, wheat, cassava. Based on this, the higher the sorghum-based business opportunity [28][29].

The IbIKK program at UWKS is finally used to realize CES-UWKS and form 26 SEUs which include training and mentoring activities on the manufacture of various sorghum products, supporting equipment, information dissemination and marketing, with product variations: seeds, rice, flour, sorghum-based bran, various cake, cookies, bakery, tape, tempeh, rice, and various non-food products such as vases, t-shirts, books, accessories, sorghum-based batik, and cosmetic products: masks. These efforts will continue to be expanded and strengthen CES-UWKS, forming a network of consortiums and sorghum producers capable of contributing and providing solutions to the nation with diversified sorghum food entrepreneurship. The Formed of CSE and SEU UWKS showed at Figure 2 [30][31].

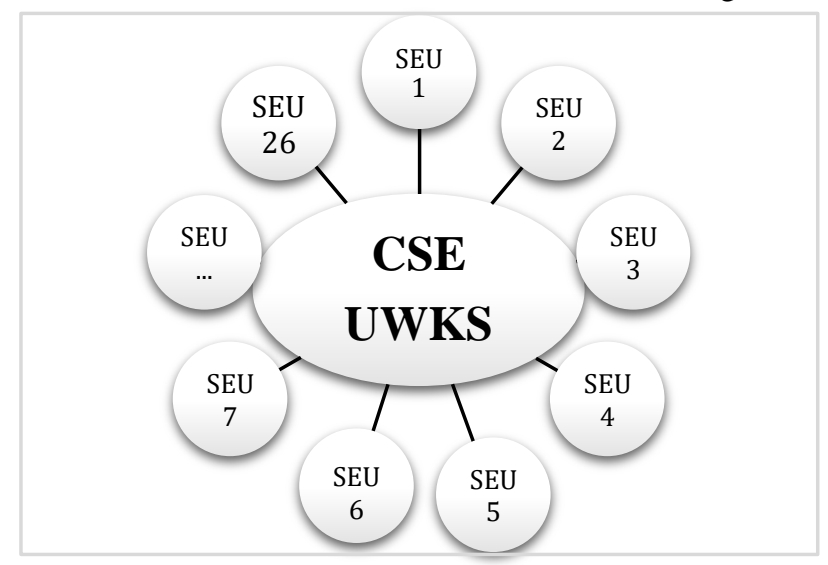

Fig. 2. The Formed of CSE and SEU UWKS

\section{Conclusion}

The formed of UWKS as Center for Sorghum Entrepreneurship (CSE) and entrepreneurship networks are created by establishing Sorghum Entrepreneurship Units (SEU) in various places, consisting of students, lecturers, and employees of UWKS, and the community so that UWKS is able to contribute and provide solution to the nation of Indonesia through the diversification of sorghum food, raising the potential of sorghum as alternative food, opening opportunities sorghum industry, created new entrepreneurs in the field of sorghum. by becoming CSE, UWKS can support the program of Resilience, Independence, and Food Sovereignty of Indonesia, and support the stabilization of production of natural sweetenerscontribute and provide solutions to the nation by producing diversification of sorghum-based food, increasing the potential of sorghum as an alternative food, opening up the opportunity for the sorghum industry, creating new entrepreneurs in the field of sorghum, which eventually can support the Indonesian Food Diversification and Food Security Program, also support the stabilization of production of natural sweeteners. 


\section{References}

[1] Noerhartati E 2010 Various Industrial Products Made from Wheat and Sorghum Agriculture Department Provincial Government of East Java

[2] Noerhartati E and Rahayuningsih T 2017 Stick Sorghum (Sorghum sp) As Food Diversification Alternative Products JRP 112 38-44

[3] Noerhartati E 2010 Various Cookies Made from Flour Sorghum Paper "Si Unyil TV TRANS 7" UWKS

[4] Noerhartati E, Rahayuningsih T, Rejeki FS, Wedowati ER 2010 Activity Report of IbM Business Group Sorghum Syrup UWKS

[5] Noerhartati E, Widiartin T, Maslihah, Karsono NW 2016 Activity Report of IbIKK Production Center of Sorghum Product at UWKS Year 1 UWKS

[6] FAO 1999 Sorghum Post-harvest Operations Food and Agriculture Organization of the United Nations

[7] Kangama CO 2005 Introduction of Sorghum AJB 47 575-579

[8] Imran P 2014 Antioxidant Perspective of Sorghum and Millet JFPP 396 1089-1097

[9] Siferow W 2014 Evaluation of Sorghum IRJASS 4 476-84

[10] Ministry of Health RI 1996 List of Food Composition Jakarta Bhratara

[11] Noerhartati E, Rahayuningsih T, Rejeki FS 2013 Activity Report of IbM Business Group of Sorghum Flour UWKS

[12] Noerhartati E 2014 Product Variety Cookies, Flakes, Sticks, Mie Sorghum Proceedings SPRINT LIPI Yogjakarta 235-238

[13] Noerhartati E and Rahayuningsih T 2012 Liquid Sugar of Sorghum Stemp: A Study of Extraction Methods Proceeding PERTETA UB Malang 60-67

[14] Noerhartati E and Rahayuningsih T 2012 Characterization of Sorghum Liquid Sugar JA 72 111119

[15] Noerhartati E and Puspitasari D 2014 Pie Sorghum Research Report UWKS

[16] Noerhartati E, Widiartin T, Karsono NW 2015 Assorted Cakes Wet Sorgum Research Report UWKS

[17] Noerhartati E and Rahayuningsih T 2015 Optimization of Sorghum Instant Noodles Products Proceeding ISREM UWKS 50-57

[18] Noerhartati E and Puspitasari D 2016 Flake Sorghum Proceeding FANRes UB Malang 83-94

[19] Noerhartati E and Rahayuningsih T 2016 Soft Bran of Sorghum Potential for High Fiber Supplement Food Proceeding IFC UKWM Surabaya 131-137

[20] Noerhartati E, Widiartin T, Maslihah, Karsono NW 2017 Activity Report of IbIKK Production Center of Sorghum Product at UWKS Year 2 UWKS

[21] Amue GJ and Adiele KC 2012 New Product Development And Consumer Innovative Behaviour EJBS 16 97-109

[22] Noerhartati E, Widiartin T, Maslihah, Karyanto NW. 2018. The Development of Market Segmentation of Sorghum Products as Functional Beverages. IOP Conf. Ser.: Mater. Sci. Eng. 434 1012169

[23] Widiartin W and E Noerhartati 2018 Build sorghum database for developing SEU digital network on sorghum website of Wijaya Kusuma Surabaya University IOP Conf Ser Mater Sci Eng 434 012253

[24] Cannon T 1978 New Product Development EJM 123217 - 248

[25] Noerhartati E 2018 Evaluation of Entrepreneurship Education on Development Program of Product Sorghum IJET 7330 400-404

[26] Noerhartati E 2017 Building a Network of Entrepreneurship Supports Sorghum Development as an Alternative Food Proceeding of National Seminar of Dies Natalis UWKS 39-48

[27] Anderson AR, and Sébastien R 2017 Towards an Entrepreneurial Theory of Practice; Emerging Ideas for Emerging Economies JEEE 92 110-120

[28] Tzokas N, Hultkinkb EJ, and Hartc S 2003 The New Product Development Process JIMM 33 619626 
[29] Agwu ME and Onwuegbuzie HN 2018 Effects of International Marketing Environments on Entrepreneurship Development. JIE 712

[30] Kim HJ 2018 Reconciling Entrepreneurial Orientation and Dynamic Capabilities: a Strategic Entrepreneurship Perspective. JE 272 180-208

[31] Noerhartati E, Widiartin T, Maslihah, Karsono NW 2018 Activity Report of IbIKK Production Center of Sorghum Product at UWKS Year 3 UWKS 